\title{
Eco-hydrologic stability zonation of dams and power plants using the combined models of SMCE and CEQUALW2
}

\author{
Rouhallah Fatahi Nafchi ${ }^{1} \cdot$ Pardis Yaghoobi ${ }^{2} \cdot$ Hamid Reaisi Vanani ${ }^{3} \cdot K$ Kaveh Ostad-Ali-Askari ${ }^{4} \oplus \cdot$ Jafar Nouri $^{5}$. \\ Bizhan Maghsoudlou ${ }^{6}$
}

Received: 18 January 2021 / Accepted: 7 May 2021 / Published online: 5 June 2021

(c) The Author(s) 2021

\begin{abstract}
Construction of dams has a significant impact on hydrological conditions of rivers. Eco-hydrology, as a sub-discipline of hydrology, focusses on ecological processes occurring within the hydrological cycle and strives to utilize them for enhancing the environmental sustainability. The aim of this study was to determine the stable and instable eco-hydrologic regions in the study area. First, the factors affecting the eco-hydrologic stability were selected according to field surveys. Afterwards, the layers related to each factor were prepared in geographic information system (GIS) and ArcGIS 10 software. These factors were also weighted using the analytic hierarchy process and pairwise comparisons. Ultimately, the final map was prepared by integrating and determining the homogenous units. The CEQUALW2 software, as a water quality and hydrodynamic model, was used to confirm the accuracy of the quality data and to perform the water quality simulation in the studied dam. According to the results, pollutant source and water quality were found to be the most important factors. The final map indicated that most of the areas had not a suitable condition in terms of stability at the downstream reaches.
\end{abstract}

Keywords CEQUALW2 Software · Eco-Hydrology (EH) · Dam · Geographic Information System (GIS) · Power Plant · Spatial Multi-Criteria Evaluation (SMCE)

Rouhallah Fatahi Nafchi

fatahi2@gmail.com

Kaveh Ostad-Ali-Askari

ostadaliaskari.k@of.iut.ac.ir

1 Department of Water Engineering, College of Agriculture, Shahrekord University, Shahrekord 8818634141, Iran

2 Department of Environmental Management, Graduate School of Natural Resources and Environment, Science and Research Branch, Islamic Azad University, Tehran, Iran

3 Department of Water Engineering, College of Agriculture, Shahrekord University Shahrekord, Shahrekord 8818634141, Iran

4 Department of Water Engineering, College of Agriculture, Isfahan University of Technology, Isfahan 8415683111, Iran

5 Department of Environmental Health Engineering, School of Public Health, Tehran University of Medical Sciences, Tehran, Iran

6 Department of the Environment, Faculty of Natural Resources, Meybod Branch, Islamic Azad University, Meybod, Iran

\author{
Abbreviations \\ AHP Analytic Hierarchy Process \\ EH Eco-Hydrology \\ GIS Geographic Information System \\ SMCE Spatial Nulti-Criteria Evaluation
}

\section{Introduction}

Sedimentation, water contamination, habitat destruction and overexploitation are known to be responsible for major environmental problems. Most of these problems are triggered through the interaction between lakes and adjacent catchment areas. Eco-hydrology (EH) encourages the efforts to solve the problems integratively by increasing the understanding of key processes in the inland water carrying capacity and the resilience to the environmental stresses (Chrismadha and Haryani 2011). The eco-hydrological approach can be potentially applied to overcome various problems in lakes and reservoirs. This approach can be considered efficient as it is mostly focused on better understanding of key processes that largely determine the sustainability of lakes, both in terms of hydrology and ecological aspect, 
particularly the habitat functions, to support biodiversity and bio-productivity (Chrismadha and Haryani 2011). River network structures and their embedded hydrologic dynamics play an important role in eco-hydrological stability (Derakhshannia et al. 2020). In fact, they provide supporting landscapes for ecological processes, many of which are essential to human life and societies (Rinaldo et al. 2018). Within riverine systems, flow plays an essential role in ecosystem structure and function, as it controls many important abiotic conditions. The characteristics of flow represent the environmental conditions such as current velocity, substratum stability, channel geomorphology, water temperature and chemistry and habitat area (OstadAli-Askari et al. 2018). Additionally, extreme flood events play a principal role in influencing the structure and function of lotic ecosystem. Although dams provide the society with many benefits, their construction for regulating the river flow rates changes the quantity and quality of water (do Vasco et al. 2019). By altering flow of water nutrients, sediments, energy and biota in a river, dams induce various negative effects and threaten the health of riverine ecosystems (Bevelhimer et al. 2015). In many cases, these ecological effects put pressure on the societies that interact with and depend on the natural resources provided by these ecosystems. Dam construction can affect the upstream and downstream river reaches in different ways. As the most obvious impacts of dam construction on upstream, the created reservoir floods the riparian and adjacent lands and transforms lotic environments to lentic or semi-lentic systems. The impacts of dam on downstream are less acute and include the continuous impacts as a result of permanent change in flow regime. Typically, dams affect the flow by reducing the magnitude of flood, increasing the base flow and increasing the number and rate of changes of reversals in discharge. The stunted flood pulses and the increased base flow reduce the downstream floodplain habitats and encourage the encroachment of upland vegetation, resulting in degradation of floodplain forests and loss of biodiversity. Therefore, eco-hydrology has been proposed as the best environmental management method to achieve sustainable development. Eco-hydrology is based on the fact that environmental degradation can only be remedied by restoring some of the functions of an ecosystem and helping a partially restored system to improve itself naturally (Jørgensen 2016). Furthermore, in freshwater, ecohydrology has been successfully applied to the constructed wetlands, rivers and floodplains, for the issues concerning aquaculture and management of shorelines and river beds to maximize fish yield and improve water quality in reservoirs (Wolanski 2007).

Hoenke et al. (2014) applied a GIS-based approach to prioritize the dams for removal based on the presented ecohydrologic and social metrics. They found that the dams with the highest ranking in ecological prioritization were located on reaches of high habitat quality and longer connected river miles (Ostad-Ali-Askari and Shayannejad 2021). Hayati et al. (2013) used an organized three-step road network developed by DELPHI, AHP and spatial multicriteria evaluation (SMCE) in ArcGIS in order to manage the forest resources sustainability (Chakroun et al. 2015). They reported that these models were useful for detecting the roads. Ahmadpour (2013) used five hydrological methods ([1) FDC, (2) Tenant, (3) RVA, (4) FDC shifting and (5) DRM) for ecological assessment of Nazlu River and concluded that protection of the river required a continuous flow supply of $0.8-8.0 \mathrm{~m}^{3} / \mathrm{s}$. Zeng et al. (2012) developed a web-based decision support system for integrated water resources management based on genetic algorithm as a dss. They demonstrated that the dss was very helpful to deal with complex problems in water resources management and could be used in similar cities. Mahmoudian and Talebbeydokhti (2013) utilized the IHA/RVA method to assess the hydrological changes of Neka River and concluded that the factors negatively affecting the eco-hydrological conditions of the river were responsible for destruction of the ecosystem (Kothari and Mishra 2015). Zalewski (2011) investigated the eco-hydrology theory as a comprehensive approach and proved that obtaining such multi-science knowledge required specific consideration of the hierarchy of adjuster factors involved in interactions of water vegetation and animal species of the ecosystem. Negussie et al. (2011) used Gomera River basin, as one of the eco-hydrologic exhibition sites, for balancing the eco-hydrologic principles and resolving the environmental problems and finally established a regional center for eco-hydrology. Madadi (2011) employed the hydrologic variation indices and different methods to evaluate the effect of Karkheh Dam on eco-hydrologic conditions of downstream. He showed that Karkheh Dam extremely changed the natural flow, range of conditions and spatial variations. Hipsey et al. (2011) used a systemic model for restoring the natural biodiversity in Bryde Lake in south west of Australia to develop an eco-hydrologic model for evaluating the response of flood plain pond to altered flow discharges (Zalewski 2015). He indicated that the model could predict flow discharge and inundation of the flood plain. Zalewski (2010) believed that eco-hydrology, as a framework presented in the international hydrological program of UNESCO, can be used (1) to slow down water exchange between atmosphere and sea in order to reduce flood and drought effects; (2) to regulate and reduce pollutants discharged into the aquatic systems; and (3) to harmonize the ecosystem potential and society requirements. Debele et al. (2006) applied two strong models of soil and water assessment tool (SWAT) and CEQUALW2 for better management of water resources in a complex river basin. They concluded that these models were compatible and could be used for evaluation of water 
resources in complex basins. Latyan dam was constructed to store and adjust the flow of Jajrood River and supply a part of water needed for Tehran's residents and Varamin Plain's agriculture (Fuladipanah and Jorabloo 2015). Considering sustainable development and conservation of natural ecological factors, water releasing would be necessary for stability, regeneration and improvement of water ecosystem in lowland areas, self-purification of rivers and maintenance of water quality (Ostad-Ali-Askari et al. 2019; Hera et al. 2016; Golian et al. 2020). The aims of this study are to map eco-hydrologic stability of Latyan dam basin and determine the eco-hydrologically stable and instable places in the study area using the combined models of CEQUALW2 water quality Simulation and SMCE. Moreover, DELPHI method and Analytical Hierarchy Process (AHP) were used in the statistical approach adopted in this study. Geographic Information System (GIS) was also applied for zonation. This study has been performed in Latyan Dam of Tehran in 2015.

\section{Materials and methods}

\section{Study area}

The study area is located between longitudes of $51^{\circ} 23^{\prime}$ to $51^{\circ} 55^{\prime} \mathrm{E}$ and latitudes of $35^{\circ} 45^{\prime}$ to $36^{\circ} 50^{\prime} \mathrm{N}$. The average annual rainfall in Roodak, Latyan and Mamloo stations, which are close to the watershed, are 580, 413 and $249 \mathrm{~mm}$, respectively. The study area, with an area of $69,800 \mathrm{~km}^{2}$, includes two classes of antisols and inceptisols with different types of land use such as bare lands, rangeland, forest, shrub lands and residential areas. The average annual flow of the river in the studied watershed is $350000000000 \mathrm{~m}^{3}$. Latyan Dam, with a height of $107 \mathrm{~m}$, has been constructed on the river in outlet of the study area.

\section{Data preparation}

The topography, lithology, soil, land use, location of the areas under conservation maps of the Department of Environment were used. To simulate different conditions including temperature lamination and eutrophication and to simulate quality parameters including oxygen, nitrate, phosphate, biochemical oxygen demand (BOD) and algae in Latyan Dam, the CEQUALW2 model was used. According to the experts' opinions collected by a questionnaire, the mentioned parameters were classified into five groups of physical, biologic, economic and social, contaminant and water quality factors. In the next step, the questionnaires were filled in by several qualified experts and analyzed by DELPHI model. Each question covered five importance degrees of $1,3,5,7$ and 9 to be selected by the experts. After validation of the questionnaires by geometric average, 19 out of 30 questionnaires were selected for analytic hierarchy process (AHP). Using Cronbach's alpha, the validity and reliability of the questionnaires were tested by SPSS 20 software. Subsequently, CEQUALW2 was used for simulation of the water quality. Furthermore, ArcGIS and SMCE models were used for zoning and representing eco-hydrologically stable and instable zones.

\section{Analytical hierarchy process (AHP)}

AHP is based on some principles including decomposition and comparative judgment of priorities (Saaty 1980). This approach relies on a pairwise comparison as an input implementing a point scale to show individual judgments when comparing each pair of factors (Saaty 1980; Jamali et al. 2014). AHP produces relative weights as output and thus builds a ratio matrix which is checked for consistency based on the standard AHP methodology (Saaty 1980). However, as a weakness, the uncertainty related to mapping of the decision maker's judgment about priority number is not considered by AHP, and preference of the decision maker has a high influence on the result of AHP (Kordi 2008). SMCE can be used to reduce the weak points of AHP.

\section{Spatial multi-criteria evaluation (SMCE)}

SMCE, as a combination of multi-criteria evaluation and GIS, was introduced in 1980 (Looijen 2009). SMCE is used to solve the spatial problems, where goals, factors and other elements in programing are related to the space. ITC Center has developed SMCE in ILWIS software. Outputs of SMCE are maps of a specific region (i.e., factors or elements) and a tree of factors including method of classification, standardization and weighting of factors (Jamali et al. 2014).

\section{CEQUALW2 model}

CEQUALW2 model was developed for water quality and hydrodynamic modeling based on the experiment database of American Rivers. CEQUALW2 is a two-dimensioned numerical, hydrodynamic, water quality model. This model contains both water quality and hydrodynamic modules. Its calculations are affected by variable density obtained from temperature, saltiness, solutes and suspended material. CEQUALW2 is capable of predicting the changes in water table, velocity and temperature of water. Since temperature affects the water density, temperature calculation has been included in the hydrodynamic sub-system and should not be deleted. 
Table 1 Weights of the physical factor assigned by AHP

\begin{tabular}{|c|c|c|c|c|c|c|}
\hline Factor & Climate & Topography & Hydrology & Lithology & Soil & Weights \\
\hline Climate & & 1.5 & 1.8 & 2 & 2.3 & 0.36 \\
\hline Topography & & & 1.3 & 1.6 & 1.9 & 0.26 \\
\hline Hydrology & & & & 1.2 & 1.5 & 0.18 \\
\hline Lithology & & & & & 1 & 0.1 \\
\hline Soil & & & & & & 0.1 \\
\hline
\end{tabular}

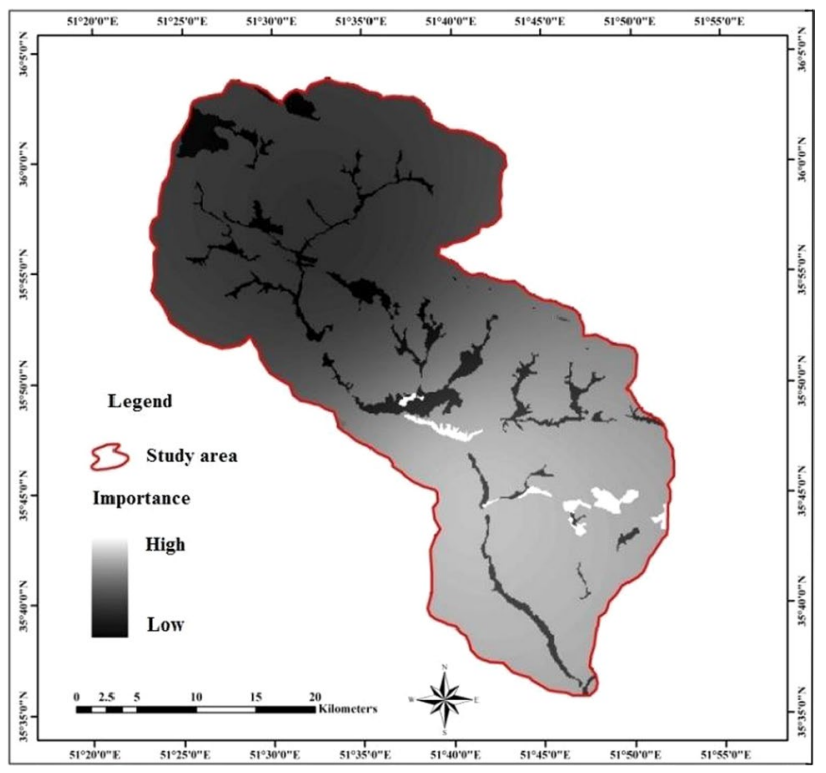

Fig. 1 Eco-hydrologic stability map of the biological factor

Table 2 Weights of the water quality factor assigned by AHP

\begin{tabular}{|c|c|c|c|c|}
\hline Factor & Physical & Chemical & Biologic & Weights \\
\hline Physical & & 1.5 & 1.7 & 0.45 \\
\hline Chemical & & & 1.1 & 0.3 \\
\hline Biologic & & & & 0.25 \\
\hline
\end{tabular}

\section{Results and discussion}

In the first step, five dominant factors related to eco-hydrologic stability were calculated using different sub-factors. For example, the physical factor was determined using five sub-factors of climate, topography, hydrology and water resources, geology and soil and land capability (Table 1). The biological factor included vegetation cover, aquatic system and distance of rivers from susceptible and important ecologic locations (Fig. 1). In the water quality factor, physical and chemical quality, biologic water quality and bacteriologic water quality were considered to produce

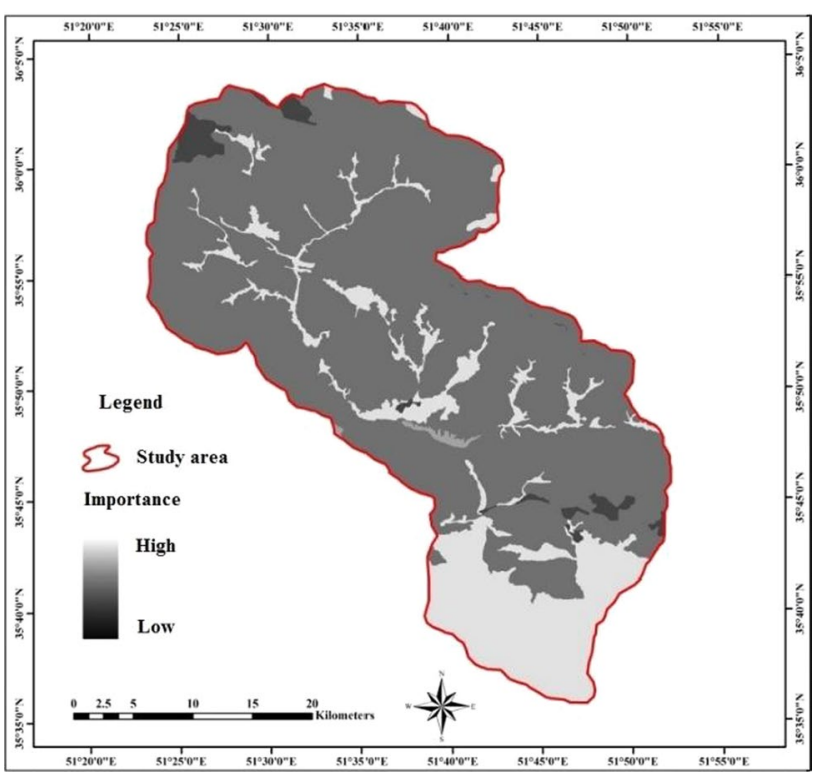

Fig. 2 Eco-hydrologic stability map of the social-economic-cultural factor

Table 3 Weights of the pollutant resources factor assigned by AHP

\begin{tabular}{|c|c|c|c|c|c|}
\hline Factor & Industrial & Civic & Mine & Agricultural & Weights \\
\hline Industrial & & 2 & 3 & 4 & 0.45 \\
\hline Civic & & & 2 & 3 & 0.25 \\
\hline Mine & & & & 1 & 0.15 \\
\hline Agricultural & & & & & 0.15 \\
\hline
\end{tabular}

the final map (Table 2). Occupation types and population were considered in the economic, social and cultural factor (Fig. 2). Finally, to investigate the pollutant sources factor, the industrial, civic, mine and agricultural pollutants in the study were considered (Table 3 ).

Using AHP, the specific weights were assigned to different factors and the eco-hydrological stability map was produced. Table 4 shows the results of AHP for different factors in the present study. It can be seen that the pollutant sources have the highest weight of 0.43 . Moreover, the water quality 
Table 4 Weights of different factors obtained based on the goal

\begin{tabular}{|c|c|c|c|c|c|c|}
\hline Factor & $\begin{array}{l}\text { Pollutant } \\
\text { resources }\end{array}$ & Water quality & $\begin{array}{l}\text { Social, } \\
\text { economic and } \\
\text { cultural }\end{array}$ & Physical & Biological & Weights \\
\hline Pollutant resources & & 1.5 & 2 & 2.5 & 3 & 0.43 \\
\hline Water quality & & & 1.5 & 2 & 2.5 & 0.28 \\
\hline Social, economic and cultural & & & & 1.5 & 2 & 0.15 \\
\hline Physical & & & & & 1 & 0.07 \\
\hline Biological & & & & & & 0.07 \\
\hline
\end{tabular}

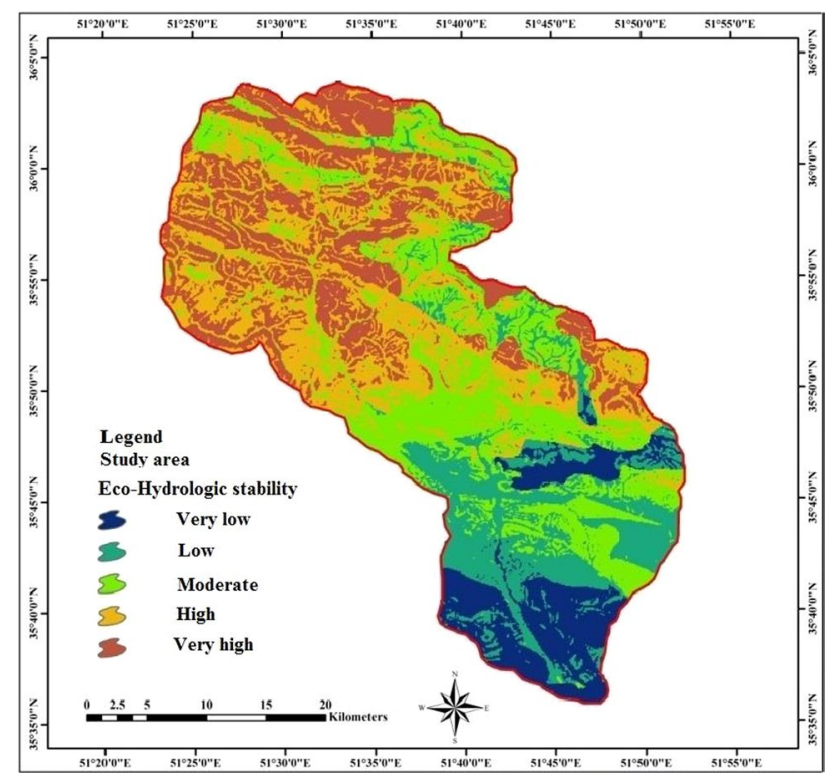

Fig. 3 Classified eco-hydrologic stability map

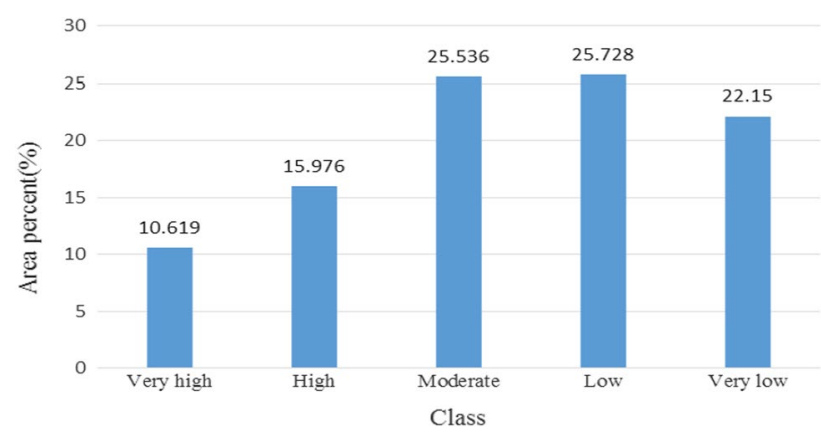

Fig. 4 The area related to each class of the eco-hydrologic stability map

factor and the social, economic and cultural factor have the weights of 0.28 and 0.15 , respectively. However, both physical and biological factors have the lowest weight of 0.07 .
The final eco-hydrologic stability map was presented using Eq. (1).

Map $=0.43 *$ Pollutant resources +0.28

$$
\begin{aligned}
& * \text { Water quality }+0.15 \\
& * \text { Social, economic and cultural } \\
& +0.07 * \text { Physical }+0.07 * \text { Biological }
\end{aligned}
$$

Based on the experts' opinions, the final eco-hydrological stability map was then classified into five classes of very high, high, moderate, low and very low (Fig. 3). According to Fig. 3, the northern parts of the study area have high and very high eco-hydrologic stabilities, while the southern parts have low and very low eco-hydrologic stabilities.

The area related to each class of the eco-hydrologic stability map is represented in Fig. 4. According to Fig. 4, low, moderate, very low, high and very high classes occupy $25.73 \%, 25.54 \%, 22.1 \%, 15.976 \%$ and $10.619 \%$ of the study area, respectively.

\section{Conclusion}

Among the various models, CEQUALW2 model was used to simulate the quality of inlet and outlet water of Latyan dam reservoir and to investigate the thermal layering of the reservoir and the biological conditions of the downstream ecosystem. A combination of AHP method and ArcGIS software was used to weigh and integrate the main components in order to obtain the eco-hydrologic zones in terms of sustainability. Results of the AHP method indicated that among the five components studied, pollutant resources and water quality had higher weights, and both physical and biological factors had the lowest weight (0.07). The final map of eco-hydrologic stability zoning was obtained by calculating the total weights of the target criterion. Considering the complexity of making decision based on the obtained map, it was classified into five classes using the experts' opinions and statistical methods. The defined classes included the zones with very high (10.6\%), high $(15.9 \%)$, moderate $(25.5 \%)$, low $(25.7 \%)$ and very low 
(22.1\%) eco-hydrologic stabilities. According to the final classification map, most of the areas at the northern parts had very high and high eco-hydrologic stabilities, and the southern parts had very low and low eco-hydrologic stabilities. The results also showed that the areas with very low and low ecologically stable conditions could be regarded as sensitive ecological areas and should be placed at the top priority in allocating the minimum environmental water requirement.

Acknowledgements The Authors would like to acknowledge Research Office of Tehran Regional Water and Department of the Environment as well as the consulting engineers for providing data, information and valuable recommendations.

Author's Contributions All authors designed the study, collected data, wrote the manuscript and revised it.

Funding Funding information is not applicable. No funding was received. No grants were received.

Availability of data and materials Some or all data, models or code generated or used during the study are available from the corresponding author by request.

\section{Declarations}

Conflict of interest The authors declare that there is no conflict of interests regarding the publication of this manuscript. In addition, the ethical issues, including plagiarism, informed consent, misconduct, data fabrication and/or falsification, double publication and/or submission and redundancies have been completely observed by the authors.

Ethical approval The present Study and ethical aspect was approved by Water Engineering Department, College of Agriculture, Shahrekord University, Shahrekord, Postal Code: 8818634141, Iran.

Consent to participate All authors designed the study, collected data, wrote the manuscript and revised it.

Consent to publish All authors agree to publish this manuscript. There is no conflict of interest.

Open Access This article is licensed under a Creative Commons Attribution 4.0 International License, which permits use, sharing, adaptation, distribution and reproduction in any medium or format, as long as you give appropriate credit to the original author(s) and the source, provide a link to the Creative Commons licence, and indicate if changes were made. The images or other third party material in this article are included in the article's Creative Commons licence, unless indicated otherwise in a credit line to the material. If material is not included in the article's Creative Commons licence and your intended use is not permitted by statutory regulation or exceeds the permitted use, you will need to obtain permission directly from the copyright holder. To view a copy of this licence, visit http://creativecommons.org/licenses/by/4.0/.

\section{References}

Ahmadpour T (2013) Indicators of hydrological variable regime in the rivers environmental assessment. Department of water engineering, university of Urimiye.

Bevelhimer MS, Mcmanamay RA, Oconnor B (2015) Characterizing sub-daily flow regimes: implications of hydrologic resolution on eco-hydrology studies. J River Res Appl 31:867

Chakroun H, Benabdallah S, Lili Chabaane Z (2015) Spatial decision support systems integrating ecohydrology in limited water resources regions. Univ Tunis El Manar Lab Water Environ Model 39:163

Chrismadha T, Haryani GS (2011) Eco-hydrological application in lake management. In: Proceedings national symposium on ecohydrology Jakarta 23

Debele B, Srinivasan R, Parlange JY (2006) Coupling upland watershed and downstream waterbody hydrodynamic and water quality models (SWAT and CE-QUAL-W2) for better water resources management in complex river basins. J Environ Model Assess 13:135

Derakhshannia M, Dalvand S, Asakereh B, Ostad-Ali-Askari K (2020) Corrosion and deposition in Karoon River Iran based on hydrometric stations. Intern J Hydrol Sci Techol 10(4):334. https://doi.org/10.1504/IJHST.2020.108264

do Vasco AN, de Oliveira Aguiar Netto A, da Silva MG (2019) The influence of dams on ecohydrological conditions in the Sao Francisco River Basin Brazil. J Ecohydrol Hydrobiol 19:4

Fuladipanah M, Jorabloo M (2015) Hydrological method to evaluate environmental flow (case study: gharasou river, Ardabil). J Environ Ecol Geol Geophys Eng 9:62

Golian M, Katibeh H, Singh VP, Ostad-Ali-Askari K, Rostami HT (2020) Prediction of tunnelling impact on flow rates of adjacent extraction water wells. Q J Eng Geol Hydrogeol 53(2):236-251. https://doi.org/10.1144/qjegh2019-055

Hayati E, Majnounian B, Abdi E (2013) An expert-based approach to forest road network planning by combining Delphi and spatial multi-criteria evaluation. J Environ Monit Assess 185:1767

Hera ADL, Gurrieri J, Puri S, Custodio E (2016) Eco-hydrology and hydrogeological processes: ground water-ecosystem interactions with special emphasis on abiotic processes. J Ecohyd 16:99

Hipsey MR, Vogwill R, Farmer D, Busch BD (2011) A multiscale eco-hydrological model for assessing floodplain wetland response to altered flow regimes. Int Congress Model Simul Perth Aust 1:3712

Hoenke MK, Kumar M, Batt L (2014) A GIS based approach for prioritizing dams for potential removal. J Ecol Eng 64:27

Jamali IA, Mörtberg U, Olofsson B, Shafique M (2014) A spatial multi-criteria analysis approach for locating suitable sites for construction of subsurface dams in northern Pakistan. J Water Resour Manag 28:5157

Jørgensen SE (2016) Eco-hydrology as an important concept and tool in environmental management. J Eco-Hyd 16:4

Kordi M (2008) Comparison of fuzzy and crisp analytic hierarchy process (AHP) methods for spatial multicriteria decision analysis in GIS Master's Thesis in Geomatics Department of techoology and built environment University of Gavle.

Kothari M, Mishra SK (2015) Environmental flows assessment by drought analysis. Int J Eng Adv Technol 4:171 
Looijen J (2009) EIA and SEA: environmental impact assessment and strategic environmental assessment using spatial decision support tools: distance education Enschede university of ITC.

Madadi H (2011) Assessment of karkheh dam impacts on eco-hydrological downstream conditions in southwest of Iran. World J Sci Technol 1:1

Mahmoudian L, Talebbeydokhti N (2013) Assessment of river management on eco-hydrological conditions in the Neka river. Iran Int Conf Environ Crisis Solut. 2757-2774

Negussie YZ, Urbaniak M, Zalewski M (2011) Ecohydrology for a sustainable future in Africa the cases of ethiopia kenya and tanzania. J Ecohydrol Hydrobiol 11:223

Ostad-Ali-Askari K, Shayannejad M (2021) Quantity and quality modelling of groundwater to manage water resources in IsfahanBorkhar Aquifer. Environ Dev Sustain. https://doi.org/10.1007/ s10668-021-01323-1

Ostad-Ali-Askar K, Su R, Liu L (2018) Water resources and climate change. J Water Climate Change 9(2):239. https://doi.org/10. 2166/wcc.2018.999

Ostad-Ali-Askari K, Ghorbanizadeh Kharazi H, Shayannejad M, Zareian MJ (2019) Effect of management strategies on reducing negative impacts of climate change on water resources of the Isfahan-Borkhar aquifer using MODFLOW. River Res Appl 35(6):611-631. https://doi.org/10.1002/rra.3463

Rinaldo A, Gatto M, Rodriguez-itrube I (2018) River networks as ecological corridors: a coherent ecohydrological perspective. J Adv Water Resour 112:32
Saaty TL (1980) The analytic hierarchy process: planning priority setting resource allocation. Mc Grow Hill, New York, p 287

Timchenko V (2016) Ecological hydrology (eco-hydrology) as a part of the aquatic ecology. J Ecohyd Hydrol 16:117

Wang Y, Rhoads BL, Wang D (2016) Assessment of the flow regime alterations in the middle reach of the Yangtze River associated with dam construction: potential ecological implications. J Hydrol Process 30(21):3949-3966

Wolanski E (2007) Ecohydrology solutions. J Estuarine Ecohydrology.12

Zalewski M (2010) Eco-hydrology for compensation of Global Change Braz. J Biol 70:689

Zalewski M (2011) Eco-hydrology- integrative science for sustainable water environment and society especially for large rivers. In: International conference on the status and future of the world's large rivers international conference on the status and future of the world's large rivers. Vienna 11-14 April.

Zalewski M (2015) Eco-hydrology and hydrologic engineering: regulation of hydrology-biota interactions for sustainability. J Hydrol Eng 20:1

Zeng Y, Cai Y, Jia P, Jee H (2012) Development of a web-based decision support system for supporting integrated water resources management in Daegu city South Korea. J Expert Syst Appl 39:10091

Publisher's Note Springer Nature remains neutral with regard to jurisdictional claims in published maps and institutional affiliations. 